\title{
„Zupełnie inne miasto”. Obrazy warszawskiego getta w polskiej literaturze dziecięcej XXI wieku
}

\section{Abstrakt:}

Artykuł jest poświęcony analizie przedstawień warszawskiego getta we współczesnej polskiej literaturze dziecięcej. W pierwszej części zinterpretowana zostaje warstwa tekstowa wybranych utworów, przede wszystkim Kotki Brygidy Joanny Rudniańskiej (2007), Po drugiej stronie okna. Opowieści o Januszu Korczaku Anny Czerwińskiej-Rydel (2012) oraz Arki czasu, czyli wielkiej ucieczki Rafała od kiedyś przez wtedy do teraz i wstecz Marcina Szczygielskiego (2013). Druga część zawiera analizę warstwy wizualnej, a zwłaszcza map dołączonych do książek - m.in. $\mathrm{Pa}$ miętnika Blumki Iwony Chmielewskiej (2012), dwóch wydań Arki czasu (kolejno z ilustracjami Daniela de Latoura, 2013, oraz autora powieści, 2015) i Ostatniego przedstawienia panny Esterki. Opowieści z getta warszawskiego Adama Jaromira i Gabrieli Cichowskiej (2014).

\section{Słowa kluczowe:}

Adam Jaromir, Anna Czerwińska-Rydel, Daniel de Latour, Gabriela Cichowska, getto warszawskie, Iwona Chmielewska, Joanna Rudniańska, mapy, Marcin Szczygielski, polska literatura dziecięca, Zagłada

* Krzysztof Rybak - mgr, przygotowuje rozprawę doktorską na Wydziale „Artes Liberales" Uniwersytetu Warszawskiego dotyczącą reprezentacji Zagłady Żydów w polskiej literaturze dla dzieci i młodzieży. Kieruje projektami: Oczami dziecka. Zagłada w polskiej literaturze dziecięcej i młodzieżowej po roku 1989 (DI2015 013145) realizowanym w ramach programu "Diamentowy Grant” MNiSW oraz Dziecięca książka informacyjna w XXI wieku: tendencje - metody badań - modele lektury (2020/37/N/HS2/00312) finansowanym w ramach konkursu Preludium NCN. Kontakt: km.rybak@uw.edu.pl.

1 Artykuł powstał na podstawie referatu wygłoszonego podczas XXIX Sesji Varsavianistycznej Warszawa w kulturze dla dzieci i młodzieży, sfinansowanego ze środków Biblioteki Publicznej m.st. Warszawy - Biblioteki Głównej Województwa Mazowieckiego. Część zawartych $\mathrm{w}$ niniejszym studium spostrzeżeń wynika $\mathrm{z}$ rozważań prowadzonych przeze mnie wcześniej (np. Rybak, 2019a). 
"A completely different city": Images of the Warsaw Ghetto in Polish Children's Literature of the $21^{\text {st }}$ Century

Abstract:

The paper analyses representations of the Warsaw Ghetto in contemporary Polish children's literature. The aim of the first part of the article is to interpret literary aspects of selected works, mainly Kotka Brygidy [Brygida's Kitten] by Joanna Rudniańska (2007), Po drugiej stronie okna. Opowieść o Januszu Korczaku [The Other Side of the Window: A Tale about Janusz Korczak] by Anna CzerwińskaRydel (2012), and Arka czasu, czyli wielka ucieczka Rafała od kiedyś do wtedy przez teraz i wstecz [The Ark of Time, or Rafał's Great Escape from Once Through Then Until Now and Back] by Marcin Szczygielski (2013). The second part covers an analysis of the illustrations, maps in particular, as they are part of Pamiętnik Blumki [Blumka's Diary] by Iwona Chmielewska, two editions of Arka czasu (with illustrations by Daniel de Latour, 2013, and the novel's author, 2015, respectfully), and Ostatnie przedstawienie panny Esterki. Opowieść z getta warszawskiego [Miss Esterka's Last Show: A Tale from the Warsaw Ghetto] by Adam Jaromir and Gabriela Cichowska (2014), among others.

Key words:

Adam Jaromir, Anna Czerwińska-Rydel, Daniel de Latour, Gabriela Cichowska, Warsaw Ghetto, Iwona Chmielewska, Joanna Rudniańska, maps, Marcin Szczygielski, Polish children's literature, Holocaust

D ozważania o przestrzeni warszawskiego getta we współczesnej polskiej 1 literaturze dziecięcej chciałbym rozpocząć od zacytowania dialogu z Arki czasu, czyli wielkiej ucieczki Rafała od kiedyś przez wtedy do teraz i wstecz Marcina Szczygielskiego (2013). Tytułowy bohater utworu, żydowski chłopiec, dzięki wehikułowi czasu przenosi się z okresu niemieckiej okupacji Warszawy do roku wydania powieści i wypytuje spotkaną w ogrodzie zoologicznym dziewczynkę o to, jak wygląda stolica wiele lat po wojnie:

- Jak tu jest? - pytam [...].

- Gdzie?

- W Warszawie.

- Normal. A jak ma być? [...].

- A... A Dzielnica?

- Jaka dzielnica? Która?

- No, Dzielnica. [...] Getto.

- Getto? - pyta ze zdumieniem. Nie ma takiej dzielnicy. Jest Żoliborz, Śródmieście, Praga. Ale o dzielnicy Getto nie słyszałam (s. 148). 
Ten dialog można odczytywać jako fikcyjny, ale symptomatyczny przykład społecznej niepamięci, która dotyka nie tylko wydarzeń z przeszłości, lecz także rozmaitych przestrzeni, zwłaszcza tych, których ślady trudno odnaleźć w tkance współczesnego miasta. Taką przestrzenią jest niewątpliwie opisane przez Jacka Leociaka (2011, s. 40-52) „miejsce-po-getcie” - teren, który z czasem obrósł kolejnymi warstwami zabudowań ${ }^{2}$, ale też znaczeniami symbolicznymi, trudnymi do odkodowania zarówno przez dorosłych, jak i przez dzieci. By przywrócić pamięć o tym, jaki obszar zajmowała owa część miasta, w stolicy pojawiły się artystyczne instalacje, m.in. Wielokropek Agnieszki Kurant i Anny Baumgart (2009) oraz Kładka Pamięci Tomasza Leca (2011)³. To jednak nie wszystko. Pamięć o przestrzeni może być przywracana (a raczej - kreowana) także za pomocą literatury (Buryła, 2019) ${ }^{4}$, w tym tej skierowanej do czytelnika dziecięcego (Wójcik-Dudek, 2016a) ${ }^{5}$, który poznaje świat, doświadczając tak teraźniejszości, jak przeszłości.

Rozważania czynione w niniejszym tekście są poświęcone wizerunkom warszawskiego getta zawartym we współczesnej polskiej literaturze dziecięcej mówiącej o Zagładzie Żydów. Warto na wstępie stwierdzić, że getto, a zwłaszcza getto warszawskie, jest jednym z najczęstszych miejsc akcji owych utworów ${ }^{6}$. Łączy się to $\mathrm{w}$ dużej mierze $\mathrm{z}$ postaciami związanymi $\mathrm{z}$ jego funkcjonowaniem, czyli Januszem Korczakiem i Ireną Sendlerową, których zbeletryzowane

2 Jarosław Zieliński (2014, s. 410) wymienia cztery miejsca, w których odnaleźć można resztki granic warszawskiego getta, choć tylko w jednym z nich zachował się fragment oryginalnego muru z czasów utworzenia dzielnicy. W pozostałych mieszczą się zaś ściany budynków, które znajdowały się na zmieniającej się w czasie granicy tego obszaru.

3 Pierwszy projekt składał się z balonów tworzących wielokropek wpisany w nawias (co miało symbolizować sferę przemilczeń dotyczącą Zagłady), które wisiały przez ponad miesiąc w miejscu kładki łączącej małe i duże getto przy ulicy Chłodnej. Po kilku latach w tym samym miejscu pojawiły się dwie pary słupów połączonych napowietrznymi światłowodami i fotoplastykon $\mathrm{z}$ archiwalnymi fotografiami (Kowalska-Leder, 2017, s. 267-268).

4 Sławomir Buryła (2019, s. 46) jedynie wspomina wybrane utwory dla dzieci: Szlemiela Ryszarda Marka Grońskiego (2010), Kotkę Brygidy i XY Joanny Rudniańskiej $(2007,2012)$ oraz Arkę czasu Szczygielskiego (2013).

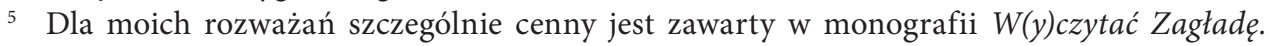
Praktyki postpamięci w polskiej literaturze XXI wieku dla dzieci i młodzieży Małgorzaty Wójcik-Dudek (2016a) rozdział Postpamięć i zarządzanie przestrzenia (s. 219-258). Na ten temat badaczka wypowiadała się w wielu innych opracowaniach (np. Wójcik-Dudek, 2014, 2016b).

6 O getcie łódzkim mówią Bezsenność Jutki Doroty Combrzyńskiej-Nogali (2012) oraz Rutka Joanny Fabickiej (2016), o getcie krakowskim - Pan Apoteker Katarzyny Ryrych (2018), a o getcie utworzonym w Gródku Jagiellońskim (dzisiejsza Ukraina) opowiadają Wysiedleni Combrzyńskiej-Nogali (2018). 
życiorysy stanowią znaczną część twórczości dla młodych czytelników poruszającej temat Holokaustu. Wywód poświęcony tytułowemu zagadnieniu został podzielony na dwie części. W pierwszej z nich skupiam się na warstwie tekstowej wybranych dzieł i omawiam sposoby opisywania przestrzeni warszawskiego getta przez ich twórców. Interesuje mnie zwłaszcza perspektywa dziecięcego bohatera i kontrast między „aryjską" a "niearyjską” stroną przedzielonej murem Warszawy ${ }^{7}$. Druga część analizy jest poświęcona ilustracjom, a zwłaszcza mapom dzielnicy żydowskiej, które towarzyszą wybranym tekstom. Kartograficzny dodatek z pozoru pełni funkcję wyłącznie informacyjną, oferując artystyczną interpretację nie tylko wypływającą z inwencji ilustratora (czasami tożsamego pisarzowi), lecz także odzwierciedlającą fabułę danego utworu. Analiza obu poziomów dzieł - werbalnego i wizualnego - daje wgląd w sposoby kreowania obrazów warszawskiego getta we współczesnych polskich książkach dla dzieci: Kotce Brygidy i XY Joanny Rudniańskiej (2007, 2012), Pamiętniku Blumki Iwony Chmielewskiej (2011), Arce czasu Szczygielskiego (2013, 2013/2015 $)$, Ostatnim przedstawieniu panny Esterki. Opowieści $z$ getta warszawskiego Adama Jaromira i Gabrieli Cichowskiej (2014), a także Po drugiej stronie okna. Opowieści o Januszu Korczaku oraz Listach w butelce. Opowieści o Irenie Sendlerowej Anny Czerwińskiej-Rydel (2012, 2018)9.

Należy zaznaczyć, że literatura dziecięca o Zagładzie charakteryzuje się mocnymi kontrastami. W wielu tekstach pojawiają się fragmenty podkreślające różnice między „przedwojną” (tego określenia używa Rudniańska, 2007, s. 18) i czasem wojny, między Polakami a Żydami, między stronami „aryjską” i „niearyjską" (Rybak, 2017; Skowera, 2014) ${ }^{10}$. W tekstach skierowanych do młodych odbiorców równie dobitnie zostaje zaprezentowany jaskrawy podział

7 Za Małgorzatą Melchior (2004) określenie „aryjski” i jego derywaty zapisuję w cudzysłowie, ponieważ, jak słusznie zwraca uwagę badaczka, ta kategoria, wprowadzona przez reżim III Rzeszy, wypływa $z$ ideologii politycznej inspirowanej rasizmem i wprowadza sztuczny podział społeczny. Zapis określenia bez cudzysłowu jest stosowany przez niektórych autorów, ponieważ - jak dowodzą - tak „używane ono było w getcie” (Engelking, Leociak, 2013, s. 22).

8 Odnoszę się też do drugiego wydania powieści, zawierającego inną warstwę ilustracyjną.

9 Informacje o innych dziecięcych (a także młodzieżowych) utworach o Zagładzie można znaleźć w internetowym katalogu stanowiącym część zrealizowanego przeze mnie projektu Oczami dziecka. Zagłada w polskiej literaturze dziecięcej i młodzieżowej po roku 1989 (Rybak, 2016-2020).

${ }_{10}$ Kwestia relacji polsko-żydowskich, w tym polskiego antysemityzmu, widzianych oczami żydowskich dzieci nie jest tematem niniejszego artykułu, ponieważ interesuje mnie przede wszystkim artystyczna kreacja przestrzeni warszawskiego getta. Więcej na ten temat przeczytać można w antologiach Dzieci żydowskie w czasach Zagłady (Orzeł, 2014) czy Piętno 
przestrzeni wyznaczany w Warszawie od listopada 1940 roku przez trzymetrowy mur. Już na poziomie językowym czytelnik może zaobserwować zmianę, która zachodzi po przesiedleniu żydowskich bohaterów do getta. Na przykład w XY Rudniańska (2012) opowiada historię rozłączonych tuż po narodzinach bliźniaczek - Hani X i Hani Y - wychowujących się w dwóch różnych rodzinach: polskiej i żydowskiej. Jak mówi narrator, w momencie utworzenia getta, "ogrodzonego wysokim murem i zamkniętego jak więzienie miasta w mieście” (s. 22), rodzina Hani X musi przeprowadzić się z przestronnego mieszkania przy ulicy Pięknej do mieszkania dziadka i babci przy Twardej, znajdującej się w getcie. Piękna znajduje się w niedalekim sąsiedztwie parku Łazienkowskiego i Alei Ujazdowskich, kojarzy się więc pozytywnie - wskazuje na to nie tylko jej położenie, lecz także sama nazwa. Wskutek antysemickiej polityki dziewczynka trafia na Twardą, która zarówno z nazwy, jak i z powodu trudnych warunków panujących w położonym tam mieszkaniu staje się symbolem diametralnej zmiany w życiu bohaterki (Wójcik-Dudek, 2016a, s. 221).

W innym utworze Rudniańskiej (2007), Kotce Brygidy, główną bohaterką jest pochodząca z katolickiej rodziny Helena, której ojciec codziennie przywozi Żydów zza muru do swojego zakładu pracy. Jak wspomina dziewczynka, „getto $\mathrm{z}$ jego opowieści było zupełnie innym miastem niż Warszawa, tłocznym i okropnie ponurym" [wyróżnienie własne] (s. 63). Helena może zobaczyć je na własne oczy, ponieważ ojciec zabiera ją na przejażdżkę tramwajem przez dzielnicę żydowską:

Helena uniosła głowę i aż krzyknęła. To miasto, przez które jechali, zniknęło. Za oknem było zupełnie inne miasto, obce i straszne. Tamto miasto było przestronne i wyzłocone słońcem, to było ciasne, szare i czarne. Ludzie nie mieścili się w nim: szli, stali, biegli, siedzieli, na chodnikach, ulicach, wszędzie, nawet $w$ otwartych oknach, widać było głowy i ręce, jakby wysypywali się z mieszkań [...].

- Patrz uważnie i zapamiętaj - powiedział ojciec [...].

Tramwaj zwolnił, ale nie zatrzymał się zupełnie. Za oknem, na małym placyku, stali ludzie. Niewyobrażalnie ściśnięty, dziwny tłum, falujący jak wzburzone jezioro [...]. Tramwaj sunął teraz $\mathrm{w}$ wąwozie pomiędzy murami i po chwili znów znalazł się w Warszawie, na normalnej, niedzielnej ulicy zalanej wiosennym słońcem (s. 76-78) ${ }^{11}$.

Zagłady (Michlic, 2020). O relacjach polsko-żydowskich i Zagładzie w literaturze dziecięcej pisałem w innym tekście (Rybak, 2020).

11 Motyw ten pojawia się również w XY: „W getcie było zupełnie inaczej niż w Warszawie: było szaro, smutno i okropnie tłoczno" (Rudniańska, 2012, s. 23). Co znaczące, w interpretacji 
Uwagę zwraca kilka elementów powyższego opisu. Jednym z nich jest tramwajowa podróż przez getto - motyw często powracający w literaturze wspomnieniowej osób nieżydowskiego pochodzenia mieszkających w Warszawie w czasie istnienia dzielnicy zamkniętej (Leociak, 2001, s. 83-84). Stosując ten motyw, Rudniańska za pomocą słów ojca Heleny podkreśla wagę doświadczenia, które staje się udziałem dziewczynki: „Patrz uważnie i zapamiętaj”. Bohaterka ma być nie tylko obserwatorem, lecz także świadkiem - ma przechować pamięć o tym, co dzieje się z ofiarami Zagłady, oraz o tym, w jakich warunkach przyszło im żyć. W dodatku autorka opisuje ulice getta jako „wąwóz pomiędzy murami”, miasto „inne, obce i straszne”, a także "ciasne, szare i czarne”, mocno kontrastując wizerunek tej przestrzeni z wyglądem pozostałych obszarów „przestronnej i wyzłoconej słońcem” Warszawy. Wyjątkowo interesujące jest myślowe umiejscowienie przez autorkę „innego miasta” niejako poza fizycznymi granicami stolicy. Być może należy to rozumieć jako zwrócenie uwagi na symboliczne wyłączenie dzielnicy zamkniętej z ziemskiej topografii, a nie jedynie jako podkreślenie faktycznej granicy w postaci muru.

Tę hipotezę motywować można również faktem, że autorzy omawianych tu utworów odwołują się do metaforyki infernalnej, w ramach której przejście między częścią „aryjską" i „niearyjską" stanowiłoby śmierć w sensie zarówno metaforycznym, jak i dosłownym - jako nieuchronne, choć odroczone w czasie pozbawienie życia. Podobną myśl wyraża wprost narrator Listów $w$ butelce Czerwińskiej-Rydel (2018), fabularyzowanej biografii Sendlerowej, stwierdzając, że "granica pomiędzy dzielnicą żydowską a resztą Warszawy była granicą życia i śmierci" (s. 24). Nieuchronność losu przesiedleńców bezkompromisowo uwydatnia Stańcia, gosposia rodziny głównej bohaterki Kotki Brygidy. Po tym, jak pojawia się u nich tytułowe zwierzę, oddane z powodu przeprowadzki właścicieli do getta, kobieta wyraża niezadowolenie, które później próbuje załagodzić pani domu:

- No, nie gniewaj się już, Stańciu. Powiedz wreszcie coś - powiedziała mama następnego ranka, nalewając mleko dla kotki na spodeczek. - Przecież ona jest u nas tylko na przechowanie. Jak oni wrócą do swojego mieszkania, to oddamy im kotkę.

- A tam, wrócą. Nie po to robią im getto, żeby mieli wrócić. Ani jeden nie wróci, sama zobaczysz - powiedziała Stańcia (Rudniańska, 2007, s. 49).

ilustratora, Jacka Ambrożewskiego, tramwaj nosi „pechowy” numer 13. 
Autorka utworu wskazuje na funeralny aspekt przymusowej przeprowadzki do getta, czyniąc z niej ostatnią drogę zamykanych w jego murach Żydów. Helena i Stańcia obserwują ich przemarsz mostem z Pragi do dzielnicy zamkniętej. Panowała wówczas cisza, niebo było szare i ciężkie, a „Żydzi wciąż szli, wchodzili do tej długiej, niskiej klatki i szli dalej, na drugą stronę rzeki, nie wiadomo dokąd" (s. 53). Kasandryczna wizja Stańci spełnia się w momencie stłumienia powstania w getcie i zniszczenia dzielnicy żydowskiej:

- Poszli z dymem do ichniego nieba - powiedziała Stańcia.

- Do jakiego ichniego nieba? - spytała Helena.

- Do żydowskiego nieba - wyjaśniła Stańcia.

I Helena przypomniała sobie, jak Żydzi z Pragi szli do getta przez most, jak szli i szli, i milcząc wchodzili w długą klatkę rozpiętą nad mostem (s. 116).

Pojmowanie przeprowadzki do getta jako ostatniej drogi Żydów zdaje się podkreślać Małgorzata Wójcik-Dudek (2016a), pisząc, że „getto jest [...] tworem szatańskim"; jak zauważa badaczka:

[...] wyliczenie oraz hiperbola wydają się dominować w stylistyce kreującej przestrzeń getta. Budują poczucie ciasnoty, ograniczenia oraz zamknięcia. Wszystkie te cechy przypominają, że miejsce, w którym znaleźli się bohaterowie, jest im zupełnie obce, bo choć topograficznie zostało już oswojone, to przecież nigdy nie będzie należeć do porządku naturalnej przestrzeni. Powstało bowiem w wyniku opresji, a to oznacza, że siłą wpisano je w pejzaż miasta (s. 222).

Mimo piekielnego charakteru getta bohaterom omawianych dzieł udaje się nieraz zagospodarować, przekształcić i oswoić tę nieprzyjazną przestrzeń (Janus-Sitarz, 2017, s. 199-200; Rybak, 2019a, s. 70-77). W poświęconej Korczakowi biografii Po drugiej stronie okna autorstwa Czerwińskiej-Rydel (2012) słowo „piekło” pojawia się kilkukrotnie jako metafora obszaru za murem: „Teraz, w tym piekle, one tym bardziej potrzebują czegoś więcej niż tylko kawałka czarnego chleba” (s. 154); „Nasze dzieci w tym piekle mają jednak względnie dobrze” (s. 158); „Wiozą ich na wschód do pracy. W najgorszym razie, gdy i nam przyjdzie pojechać, jakoś będziemy się trzymać razem. Gorszego piekła niż tu tam na pewno nie będzie" (s. 162). Jak słusznie zauważa Wójcik-Dudek (2016a, s. 115-117), Stary Doktor, stosując jedną ze swoich taktyk (w znaczeniu nadanym temu pojęciu przez Michela de Certeau ${ }^{12}$ ), zarządził w budynku

12 „Według badacza, strategie należą do rządzących, kolonizatorów, a jako że są zgodne z narzuconym prawem, mają swoje miejsce i instytucje, które przyznają lub odmawiają innym 
poważne zmiany, by uchronić przed nieprzyjazną przestrzenią wychowanków, z którymi został tam skierowany. Odbija się to w narracji książkowej:

Na ulicy Chłodnej 33 mieściło się gimnazjum. To w nim miały zamieszkać dzieci z Domu Sierot po wprowadzeniu się do getta. Okazało się jednak, że budynek jest kompletnie do tego nieprzystosowany. Trzeba było dopiero stworzyć miejsca na sypialnie, jadalnie, klasy szkolne i warsztaty. Zorganizować życie po dawne$\mathrm{mu}$, tak jakby nic się nie zmieniło. Wszystko to wymagało dużo pracy i wysiłku [...].

- Zamurujemy wejście i okna budynku od strony niemieckiej. Chcę, żeby dzieci miały widok tylko na drugą stronę. Trzeba odgrodzić je od Niemców - zadecydował Korczak [...].

- Ale przecież i tak nie da się odseparować ich od wszystkiego, co tu się dzieje powiedziała cicho pani Stefa.

- A zobaczy pani, że nam się to uda - odparł Korczak z mocą (Czerwińska-Rydel, 2012, s. 154).

Taktyka wykorzystana przez Korczaka, stojąca wbrew woli Niemców ${ }^{13}$, pozwala na odcięcie dzieci od otaczającego je horroru i oswojenie nowej, obcej i niebezpiecznej przestrzeni getta.

Złożony obraz przestrzeni i próby jej oswojenia prezentuje Szczygielski (2013) w Arce czasu. Utwór rozpoczyna się od kilkustronicowego opisu drogi głównego bohatera, Rafała, $\mathrm{z}$ domu do biblioteki, jego ulubionego miejsca w getcie. Chłopiec z niebywałą precyzją opisuje kolejne ulice (Twardą, Ciepłą, Żelazną, Leszno), sklepy i inne miejsca mijane po drodze, a czytelnik może odnieść wrażenie, że protagonista doskonale zna tę część miasta (s. 8-10). Na solidny warsztat literacki Szczygielskiego wskazują nie tylko posłowie zawierające źródła, z których korzystał, i zamieszczone $\mathrm{w}$ tekście przypisy, lecz także fakt, że bibliotekę Rafała autor umiejscawia w konkretnej lokalizacji, pod adresem Leszno 67

prawa do miejsca. Zupełnie inaczej charakteryzowane są taktyki, działania kolonizowanych, które badacz nazywa »sztuką słabego«. Ogniskują się wewnątrz pola widzenia wroga i w związku z tym nie mają swojego miejsca, a jeśli nawet je mają, to zostało ono narzucone przez kolonizatora i owych miejsc nic nie łączy z przestrzenią wolności. Taktyki pozostające w ukryciu nie mają możliwości przygotowania planu działania, który zakładałby coś, co pozostaje z nimi w sprzeczności, a mianowicie stabilizację i zakorzenienie. Aby pozostawać nieuchwytne, muszą być migotliwe i pozbawione centrum, a w tym przypominają nieco postmodernistyczną rzeczywistość, która nie mając jednej i stałej axis mundi, »wytwarza" kilka efemerycznych ośrodków" (Wójcik-Dudek, 2016a, s. 115).

13 W niniejszym tekście posługuję się określeniami „Niemiec”, „Niemcy” i „niemiecki”, ponieważ tak właśnie opisywani są antagoniści w polskich utworach dla dzieci mówiących o Zagładzie. 
(na terenie dzielnicy żydowskiej funkcjonowały co najmniej 23 biblioteki i wypożyczalnie książek, w tym placówka Centralnej Biblioteki CENTOS - zlokalizowana właśnie przy Lesznie; Engelking, Leociak, 2013, s. 582-584, 632-633). Jak słusznie zauważa Wójcik-Dudek (2016a), „chłopiec bez przeszkód dociera do [...] centrum [getta] - do biblioteki"; badaczka wysnuwa na tej podstawie wniosek, że dzielnica żydowska jest przestrzenią oswojoną przez chłopca, który czuje się tam bezpiecznie i na swój sposób mapuje teren getta, podporządkowując narzuconą formę własnym doświadczeniom lekturowym, a więc „Rafałowe getto nie przypomina przerażającego labiryntu" (s. 233).

W przeciwieństwie do badaczki uważam, że - mimo pozornej pewności siebie, którą wyraża umieszczony w tej przestrzeni bohater - kolejne wydarzenia zmuszają czytelnika do rewizji „sielankowego” obrazu Dzielnicy ${ }^{14}$. Dziadek Rafała nie chce, żeby wnuczek biegał po terenie getta, gdyż może to być niebezpieczne (Szczygielski, 2013, s. 23); chwila zamieszania i padający strzał wprowadzają chaos, a chłopiec nagle czuje się zagubiony, nie pamięta drogi do domu: getto $\mathrm{w}$ jednej chwili staje się ogromne i Rafałowi wydaje się, że go prawie nie zna (s. 39). Przerażenie budzi w nim również ciągła obecność żołnierzy niemieckich (kojarzonych przez bohatera z Morlokami, mrocznymi istotami z czytanej przezeń powieści Wehikuł czasu Herberta George’a Wellsa, 1895/1925). Podobne zagubienie i niebezpieczeństwo chłopiec odczuwa, gdy po ucieczce z getta i ukrywaniu się przez pewien czas w zoo próbuje wrócić do Dzielnicy, aby sprawdzić, co dzieje się z dziadkiem. Wtedy też spędza wiele czasu, starając się odnaleźć dogodne miejsce, gdzie mógłby pokonać mur, a gdy wreszcie trafia na trasę, którą wcześniej chodził do biblioteki, zauważa znaczącą zmianę w tej okolicy:

Wygląda to jak po przejściu huraganu - wszędzie leżą jakieś połamane przedmioty, podarte ubrania, potłuczone talerze [...]. Tumany pierza, połamane wózki, riksze. Pootwierane walizki. Biegnę znajomą drogą, przemierzałem ją tyle razy. Jakbym biegł do biblioteki. Tyle tylko, że choć droga jest znajoma, wydaje mi się, jakbym był w obcym miejscu. Nigdy nie widziałem tych ulic pustych one nigdy nie były puste [...]. To jak sen, wszystko wydaje się mało prawdziwe (Szczygielski, 2013, s. 229, 232).

Rafał wbiega na teren opustoszałego getta podczas akcji likwidacyjnej. Potencjalny dziecięcy czytelnik może tylko domyślać się losu mieszkańców Dzielnicy, a dorosłemu na myśl mogą przyjść elementy topiki Zagłady, takie jak „tumany pierza” (Dobrosielski, 2017). Puste ulice sprawiają wrażenie obcych,

14 Właśnie w ten sposób pisze o getcie Szczygielski. 
nieznanych; bohaterowi „wszystko wydaje się mało prawdziwe”. Tak znacząca różnica w odbiorze przestrzeni świadczy, z jednej strony, o ogromie zniszczeń (również w sensie symbolicznym), które dokonały się w krótkim czasie na terenie getta, z drugiej zaś - o nietrwałości wyobrażonej przez Rafała mapy Dzielnicy, poddanej rewizji niedługo po pobycie po „aryjskiej” stronie, co mogło wpłynąć na postrzeganie świata przez bohatera.

Jak wynika z omówionych przykładów, w utworach literackich dla dzieci getto zostaje wyłączone $\mathrm{z}$ tkanki Warszawy nie tylko fizycznie, lecz także symbolicznie. Jasny podział na przestrzeń „aryjską" i „niearyjską” przybliżyć może czytelnikowi konkretną sytuację dziejową, choć autorzy odwołują się do uniwersalnych przestrzeni dobra i zła, w tym do metaforyki piekła. Infernalny charakter dzielnicy żydowskiej wymusza na bohaterze dziecięcym podjęcie próby zaadaptowania się do nowej, przerażającej rzeczywistości - getto może zostać oswojone, choć nigdy w sposób całkowity. Ponadto za pomocą wyobraźni niedorośli protagoniści modyfikują tę narzuconą, obezwładniającą przestrzeń.

Podobne procesy artystyczne można dostrzec $\mathrm{w}$ warstwie graficznej wybranych publikacji, a zwłaszcza na mapach dołączonych do niektórych z nich. Elementy kartograficzne w książkach dla dzieci - w utworach zarówno historycznych, jak i przygodowych czy fantastycznych - od jakiegoś czasu są obiektem uwagi badaczy. Na przykład Björn Sundmark (2014, s. 64) wskazał kilka funkcji map towarzyszących tekstom literackim, w tym tworzenie fikcyjnej przestrzeni świata, z którym może zapoznać się czytelnik, oraz przedstawianie wybranych elementów fabularnych. Mapy stanowiące część oprawy graficznej książek dla dzieci spełniają obie te funkcje. W kontekście przykrycia terenu getta nową zabudową za wyjątkowo pomocne można uznać uświadomienie potencjalnemu czytelnikowi położenia dzielnicy żydowskiej w odniesieniu do planu współczesnej Warszawy, jak czynią choćby twórcy map dołączonych do książek Skarb getta Adama Michejdy (2019, s. 102) oraz Kto uratowat jedno zycie... Historia Ireny Sendlerowej autorstwa Ewy Nowak (2018, s. 14).

W przypadku analizowanych utworów mapy nie są jednak wyłącznie odbiciem przestrzeni realnych. Świetnie widać to w Pamiętniku Blumki Chmielewskiej, w którym plan fragmentu miasta nie tyle ukazuje położenie rzeczywistych miejsc (w tym przypadku - Domu Sierot Korczaka), ile świadczy o - przetwarzającej i kreującej na nowo przestrzeń dzielnicy - wyobraźni dziecięcej bohaterki. Kartki pamiętnika Blumki tworzą bowiem w książce siatkę ulic Warszawy (rysunek 1) ${ }^{15}$. Z kolei w oryginalnej edycji Arki czasu

15 Jak pisze Ada Bieber (2015), „,czytelnik widzi [...] nadwiślaną Warszawę z lotu ptaka. Ta perspektywa jest podobna do mapy” (s. 184). Tłumaczenie autora artykułu - Krzysztofa Rybaka. 
Szczygielskiego (2013) umieszczoną na przedniej wyklejce mapę stolicy (z zaznaczonym czerwoną linią terenem dzielnicy żydowskiej) zaludniają różne postaci: tak Rafał oraz jego grający na skrzypcach dziadek, jak Morlokowie, będący fantastycznymi odpowiednikami niemieckich żołnierzy (rysunek 2).

W tym przypadku ilustrator pierwszego wydania powieści, Daniel de Latour, zastosował perspektywę z lotu ptaka, która - według Sundmarka (2014, s. 69) - pozwala na włączenie w mapę postaci i innych elementów, które nie pojawiają się choćby w spłaszczających krajobraz ujęciach wertykalnych, wykorzystujących wyłącznie kontury i symbole kartograficzne. Hipotetyczny czytelnik dostrzega bohaterów powieści, ale też otrzymuje informację o przebiegu fabuły: ukazane zostaje pojawienie się Morloków, czyli moment, w którym Rafał po lekturze Wehikułu czasu zauważa paralele łączące dwa światy - fantastyczny i realny. Co ważne, mapa otwiera opowieść i od samego początku staje się reprezentacją myśli bohatera, otoczonego - niczym miasto - potwornymi przeciwnikami. Mapa, choć tym razem prezentująca warszawskie zoo, na terenie którego ukrywają się żydowskie dzieci po ucieczce z getta, powraca również na tylnej wyklejce, zamykającej publikację. Ponownie można zauważyć połączenie kartografii z elementami fabularnymi, a atakujący Morlokowie wieńczą opowieść, pozostawiając projektowanego czytelnika w niepewności (choć tekst główny kończy się happy endem; Rybak, 2019b, s. 17-19).

W drugim wydaniu powieści, do którego oprawę graficzną przygotował sam Szczygielski (2013/2015), obie mapy zostają inaczej zaaranżowane: pojawiają się linie wyznaczające różne drogi bohatera (tę prowadzącą do biblioteki, tę ucieczki z getta i dotarcia do ogrodu zoologicznego itd.), zamiast Morloków czytelnik widzi zaś archiwalne fotografie oraz postać protagonisty (rysunek 3). Na kontekst historyczny wskazuje również tytuł jednej z map, Miasto Rafała. Warszawa w 1942 roku, nieobecny w pierwszym wydaniu, a także informacja o dacie zamknięcia getta. Dodatkowe elementy, zarówno werbalne, jak i wizualne, odwołują się do konkretnej przestrzeni historycznej, a także do przestrzeni współczesnej czytelnikowi (uzupełniona obrysem budynku informacja o umiejscowieniu Pałacu Kultury i Nauki), brakuje w nich jednak artystycznej wizji bazującej na wyobraźni dziecięcego bohatera, który - zainspirowany dziełem Wellsa - kreuje własne spojrzenie na warszawskie getto.

Związki między imaginacją bohaterów i kartografią zauważyć można również w Ostatnim przedstawieniu panny Esterki Jaromira i Cichowskiej. Książka opowiada o działalności Domu Sierot Korczaka widzianej oczami dwóch osób: samego Henryka Goldszmita i jego wychowanki Geni. Kluczowe są zwłaszcza przygotowania do wystawienia Poczty indyjskiego poety Rabindranatha Tagore (1922; sztuka powstała w 1911 roku) w reżyserii Esterki 


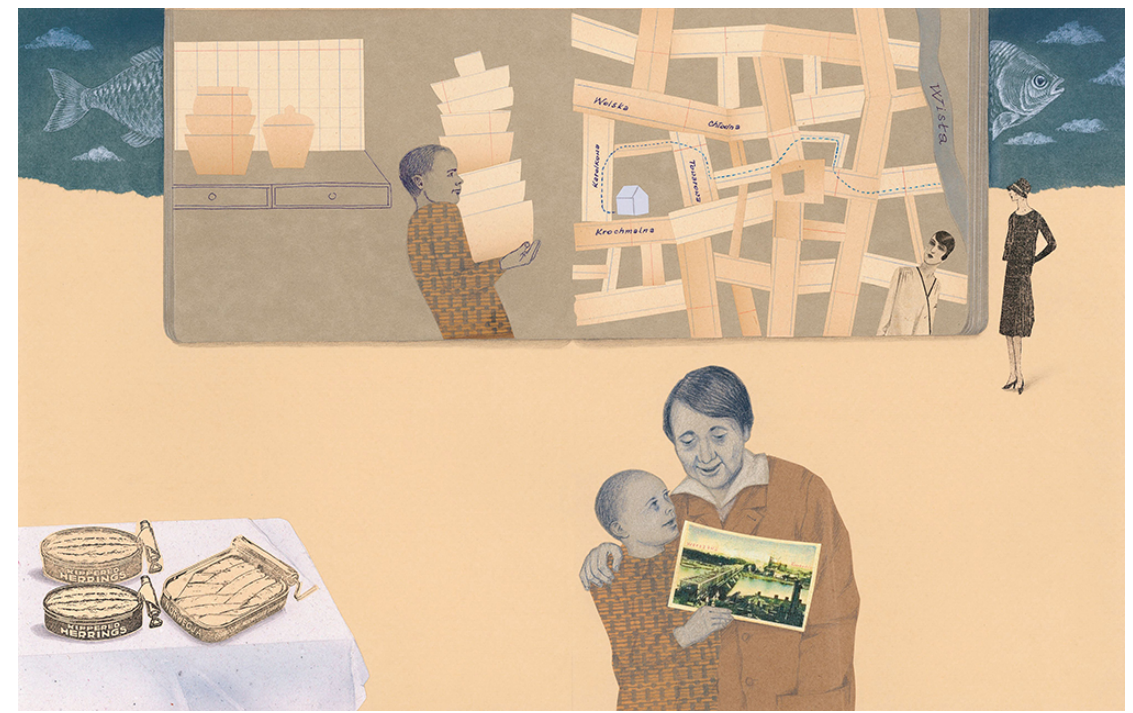

RYSUNEK 1. Iwona Chmielewska, ilustracja do Pamiętnika Blumki, (C) Iwona Chmielewska.

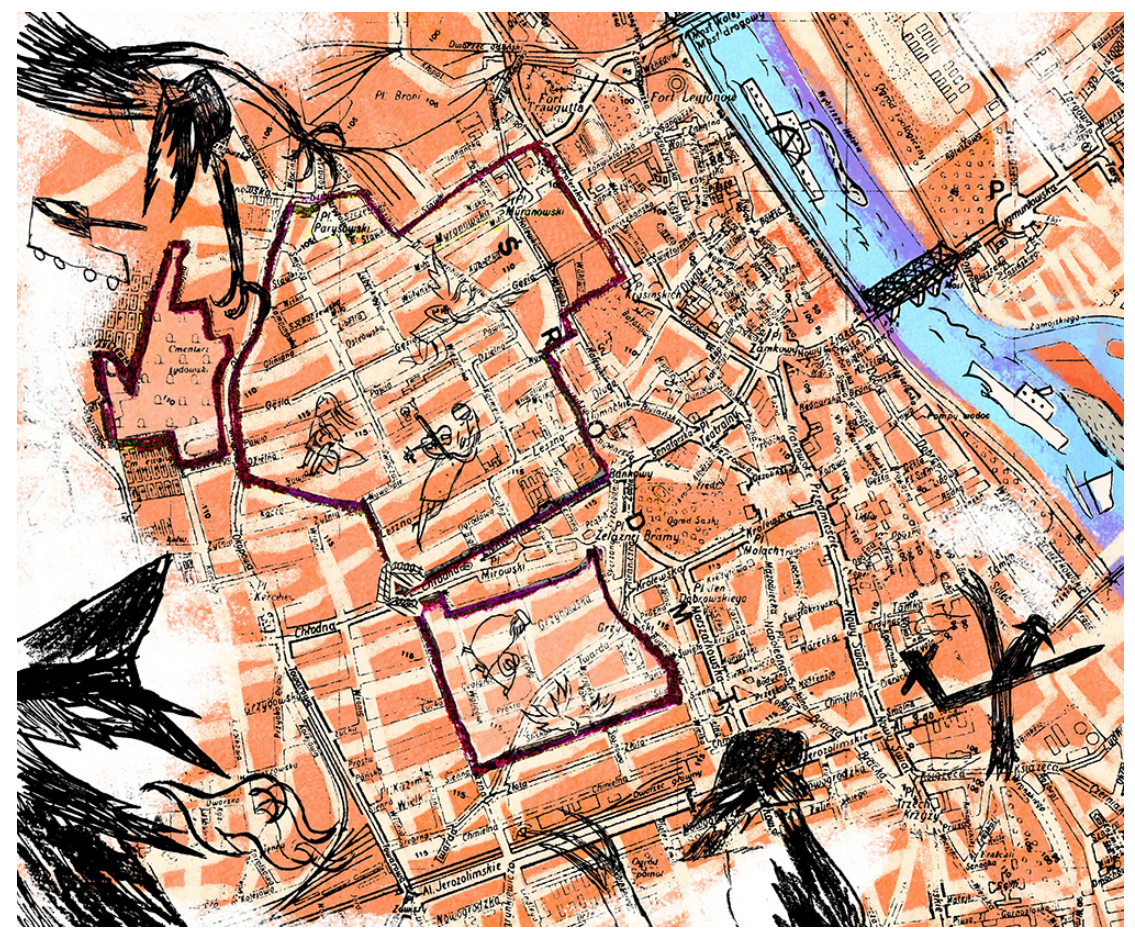

RYSUNEK 2. Daniel de Latour, ilustracja na przedniej wyklejce Arki czasu (2013), (c)Daniel de Latour. 


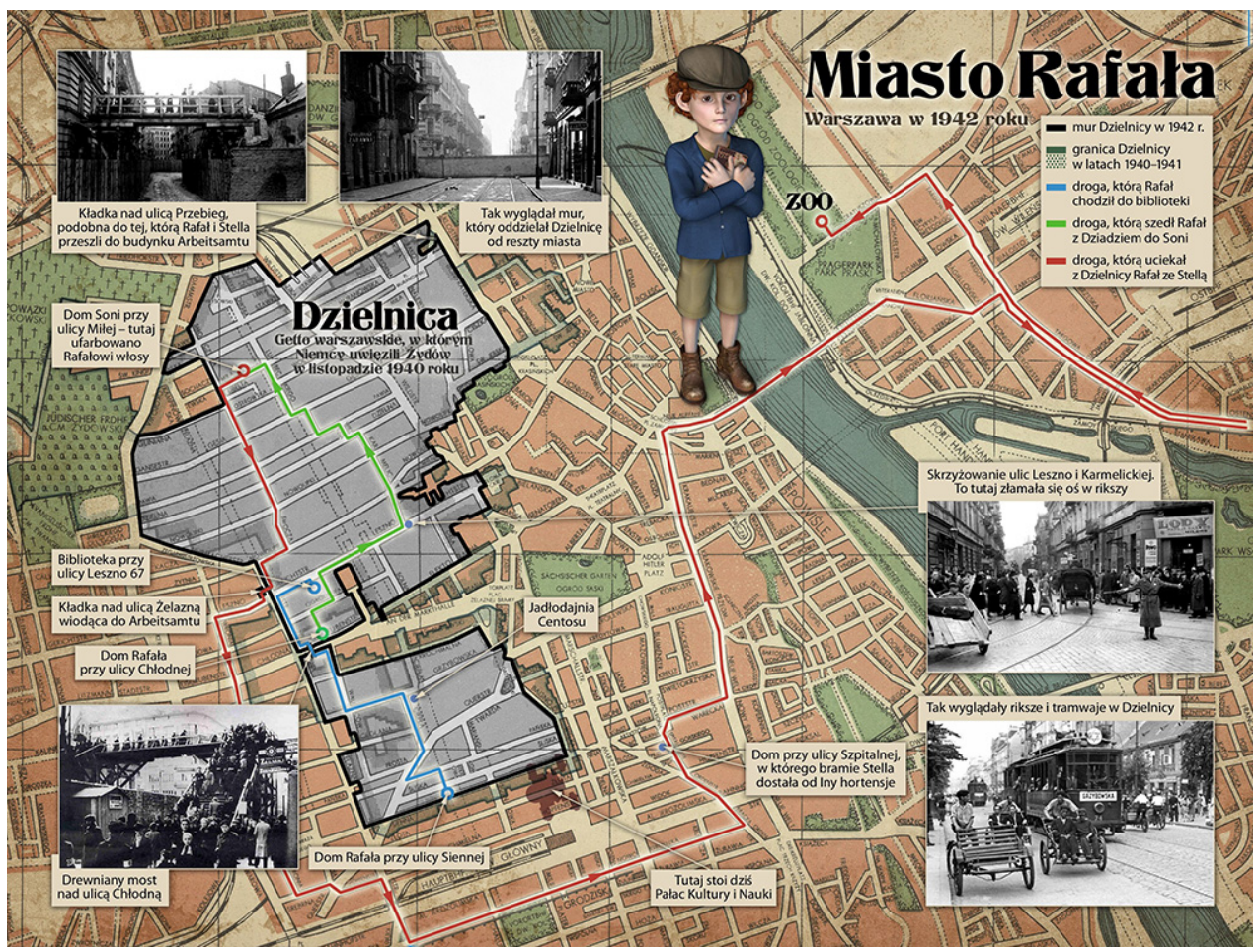

RYSUNEK 3. Marcin Szczygielski, Miasto Rafała. Warszawa w 1942 roku, ilustracja na przedniej wyklejce Arki czasu (2015), (CMarcin Szczygielski.

Winogronówny: spektakl zaprezentowany został 18 lipca 1942, dwa tygodnie przed wyprowadzeniem dzieci i pracowników sierocińca na Umschlagplatz (5 lub 6 sierpnia ${ }^{16}$ ) i wywiezieniem ich do obozu zagłady w Treblince. Historię rozpoczyna zamieszczony na okładce plan dzielnicy żydowskiej (powtórzony następnie na stronie kontrtytułowej). Co ciekawe, elementy kartografii zostają włączone w narrację wizualną kilkukrotnie. Opisowi snu Korczaka, w którym Stary Doktor spotkał brodatego mężczyznę przypominającego Tagore, towarzyszą fragmenty mapy Indii pokrywające ciało słonia. Warstwa wizualna sugeruje zatem oniryczną podróż Starego Doktora na wschód, gdzie miałby

16 Jak pisze Agnieszka Witkowska-Krych (2019): „Nie wydaje się, aby można było teraz stwierdzić ze stuprocentową pewnością, którego dnia sierpnia Korczak wraz z dziećmi i personelem Domu Sierot został pognany na Umschlagplatz, choć zdecydowanie najbardziej prawdopodobny jest dzień 5 sierpnia. Poszlaki, które na to wskazują, są bowiem mniej wątpliwe niż te, które mówią o 6 sierpnia" (s. 172). Równocześnie w innych miejscach monografii Mniej strachu. Ostatnie chwile z Januszem Korczakiem autorka przywołuje datę 5 sierpnia (np. s. 11, 175, 198, 203). 
spotkać indyjskiego poetę, co mogło zachęcić go do wystawienia w Domu Sierot Poczty (Jaromir, Cichowska, 2014, s. 65-68) ${ }^{17}$.

$\mathrm{Z}$ inspiracji pedagoga $\mathrm{w}$ sierocińcu rozpoczynają się przygotowania do spektaklu, w którym udział biorą wychowankowie przybytku. W kulminacyjnej scenie przedstawienia oba światy - szarobury i ponury getta oraz kolorowy i oniryczny Indii - spotykają się, również na planie kartograficznym. Żydowski chłopiec Abrasza, przebrany w strój Amala, głównego bohatera Poczty, zostaje zaprezentowany na tle mapy Indii, natomiast za postacią ubranej w orientalny kostium Geni widnieje fragment planu getta warszawskiego (Jaromir, Cichowska, 2014, s. 104-107). Utrzymane w czerwieniach i beżach ilustracje mogą oddawać nastrój panujący podczas przedstawienia (o czym przypominają przebrani aktorzy), ale też obrazują nakładanie się planów przestrzennych w odbiorze dziecięcych bohaterów, dla których Poczta była myślową ucieczką ponad mury dzielnicy żydowskiej ${ }^{18}$.

To (kolejne już) spotkanie dwóch światów, realnego i fantastycznego, najpełniej oddaje rozkładówka przedstawiająca mapę getta, na której umieszczono postać człowieka ubranego w orientalny strój. Ciemnoskóry mężczyzna zostaje ukazany od torsu w dół, a jego wizerunek przypomina zamieszczoną wcześniej ilustrację tańczących kobiet, opisanych jako „[b]ajadery, czyli tancerki hinduskie” (s. 89). Postać dominuje na planie dzielnicy zamkniętej, w podobny sposób siatkę ulic przysłania strona tytułowa Poczty zawierająca ilustrację leżącego w łóżku chorego Amala (rysunek 4) ${ }^{19}$. Pochodząca $z$ dramatu Tagore scena śmierci chłopca zestawiona z mapą getta może zostać odczytana jako zapowiedź dramatycznego końca Korczaka i jego wychowanków ${ }^{20}$. Ksiązka sugeruje więc, że być może przedstawienie, jak chciałaby tego Esterka, pozwoliło im na chwilę zapomnieć o przestrzeni otaczającego ich getta i przygotowało na to, co miało nastąpić.

17 Wcześniej Esterka przyniosła Korczakowi egzemplarz sztuki ze słowami: „Dzieciom brak nadziei [...]. Znam pewną indyjską bajkę. Może dodałaby im otuchy. Moglibyśmy ją wystawić" (Jaromir, Cichowska, 2014, s. 62).

18 „[Opaska] dzisiaj nie będzie ci potrzebna. Tutaj - mówi [Esterka do wychodzącej na scenę dziewczynki], wskazując na linię, gdzie zaczyna się scena - tutaj są Indie" (Jaromir, Cichowska, 2014, s. 103).

19 Ilustracja stanowi wizualny cytat z niderlandzkiego wydania Poczty w oprawie graficznej Rie Cramer (Tagore, 1916).

20 Jak można przeczytać w posłowiu: „Dnia 5 sierpnia 1942 roku - trzy tygodnie po wystawieniu Poczty - Dom Sierot został brutalnie zlikwidowany" (Jaromir, Cichowska, 2014, s. 120), a pracownicy i wychowankowie zostali skierowani na Umschlagplatz, skąd wywieziono ich do obozu zagłady w Treblince. 


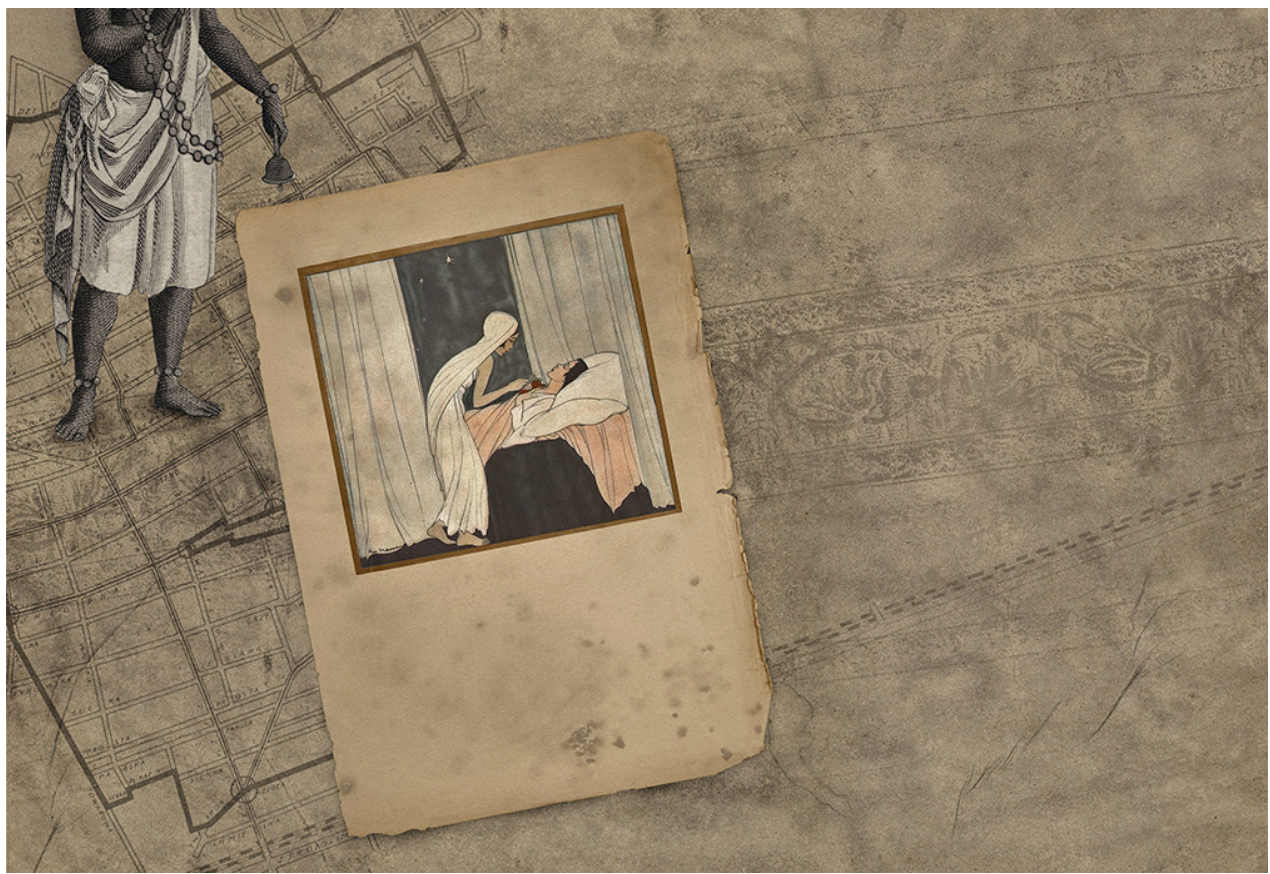

RYSUNEK 4. Gabriela Cichowska, ilustracja do Ostatniego przedstawienia panny Esterki, (Adam Jaromir i Gabriela Cichowska.

$\mathrm{Z}$ przeprowadzonej analizy warstwy werbalnej i wizualnej wybranych utworów dla dzieci mówiących o warszawskim getcie wynika, że to przestrzeń złożona i silnie wpływająca na bohaterów. W pierwszej kolejności należy zaznaczyć, że - mimo historycznie utrwalonego wyobrażenia - nie jest to obraz jednoznacznie negatywny, ponieważ dziecięcy protagoniści mogą w dzielnicy zamkniętej znaleźć również chwilę wytchnienia, jak czyni to Rafał z Arki czasu Szczygielskiego, często odwiedzający bibliotekę. Równocześnie w warstwie werbalnej getto opisywane jest przy użyciu infernalnych określeń, co zdecydowanie negatywnie wpływa na czytelniczy odbiór przestrzeni, jednocześnie sytuowanej poza realnym światem, co zwiększa dystans między czytelnikiem i miejscem akcji utworów. Wizje dzielnicy zamkniętej mają swoje źródło w relacjach nie tylko żyjących tam więźniów, lecz także świadków Zagłady przejeżdżających tramwajem przez getto, które - powtarzam tu słowa z Kotki Brygidy Rudniańskiej (2007) - staje się „zupełnie innymi miastem” (s. 63). W moim przekonaniu współistnienie tak pozytywnych, jak i negatywnych cech gettowej przestrzeni nie tyle świadczy o jej ambiwalentnym charakterze, ile wskazuje na subiektywność percepcji dziecięcego bohatera. 
Perspektywa dziecięca ujawnia się zwłaszcza w scenach ukazujących warszawskie getto oczami protagonistów, odwołujących się do pokładów wyobraźni pozwalającej przeciwstawić się przerażającej rzeczywistości. Tak dzieje się w Arce czasu Szczygielskiego, której główny bohater na ulicach Warszawy zaczyna dostrzegać straszliwych Morloków, a nie niemieckich żołnierzy. Co ważne, percepcja dziecięcego bohatera wpływa nie tylko na warstwę werbalną, lecz także wizualną, co widać w pierwszym wydaniu zilustrowanym przez de Latoura, zwłaszcza na mapach, łączących siatkę warszawskich ulic z figurami bohaterów, zarówno - w ramach tej opowieści - realnych (np. Rafał i jego dziadek), jak i wyobrażonych (potworni Morlokowie).

Znaczące, że wśród analizowanych publikacji dominują wizualne reinterpretacje topografii warszawskiego getta koncepcyjnie bliskie obrazom z pierwszego wydania Arki czasu - zaledwie w kilku książkach znaleźć można realistyczne mapy tej przestrzeni (Michejda, Nowak). Wykreowane przez Chmielewską, Jaromira i Cichowską czy wspomnianego już de Latoura ujęcia dzielnicy żydowskiej oddalają się od prezentacji czysto faktograficznej, bliższe są raczej artystycznej reinterpretacji getta widzianego oczami dziecięcych bohaterów. Wydaje się, że podobną wyobraźnią muszą wykazać się w XXI wieku młodzi czytelnicy, którzy być może będą próbowali myślowo odtworzyć przestrzeń warszawskiego getta - ukrytą pod kolejnymi warstwami zabudowań i niedostępną bezpośredniemu poznaniu ${ }^{21}$. Przewodnikiem po tym nieistniejącym mieście może być właśnie współczesna literatura dziecięca, oferująca złożony obraz - tak werbalny, jak wizualny - realiów II wojny światowej i Zagłady.

\section{Bibliografia}

Bieber, A. (2015). Mentoring in an heterotopic space - Janusz Korczak's orphanage in contemporary picture books. Filoteknos, 5, 181-189.

Buryła, S. (2019). Obraz getta warszawskiego w literaturze polskiej. Rekonesans. Konteksty Kultury, 16(1), 33-51.

Chmielewska, I. (2011). Pamiętnik Blumki. Media Rodzina.

Combrzyńska-Nogala, D. (2012). Bezsenność Jutki. Literatura.

Combrzyńska-Nogala, D. (2018). Wysiedleni. Literatura.

Czerwińska-Rydel, A. (2012). Po drugiej stronie okna. Opowieść o Januszu Korczaku. Muchomor.

${ }^{21}$ Poza ramy niniejszego studium wykraczają rozważania poświęcone relacji czytelników z otaczającą ich przestrzenią naznaczoną przeszłością. 
Czerwińska-Rydel, A. (2018). Listy w butelce. Opowieść o Irenie Sendlerowej. Literatura.

Dobrosielski, P. (2017). Pierzyna. W: J. Kowalska-Leder, P. Dobrosielski, I. Kurz, M. Szpakowska (red.), Ślady Holokaustu w imaginarium kultury polskiej (s. 341364). Wydawnictwo Krytyki Politycznej.

Engelking, B. (2013). Kultura i rozrywka. W: B. Engelking, J. Leociak, Getto warszawskie. Przewodnik po nieistniejącym mieście (s. 557-654). Stowarzyszenie Centrum Badań nad Zagładą Żydów.

Engelking, B., Leociak, J. (2013). Od autorów. W: Getto warszawskie. Przewodnik po nieistniejącym mieście (s. 11-22). Stowarzyszenie Centrum Badań nad Zagładą Żydów.

Fabicka, J. (2016). Rutka. Agora.

Janus-Sitarz, A. (2017). Gry wyobraźni a oswajanie przestrzeni strachu. Czasy Holokaustu w literaturze dla dzieci. W: A. Czabanowska-Wróbel, M. Kotkowska (red.), Wolność i wyobraźnia w literaturze dziecięcej (s. 195-206). Wydawnictwo UJ.

Jaromir, A., Cichowska, G. (2014). Ostatnie przedstawienie panny Esterki. Opowieść z getta warszawskiego. Media Rodzina.

Kurant, A., Baumgart, A. (2009). Wielokropek [instalacja]. Warszawa.

Lec, T. (2011). Kładka [instalacja]. Warszawa.

Leociak, J. (2001). Aryjskim tramwajem przez warszawskie getto, czyli hermeneutyka pustego miejsca. W: L. Burska, M. Zaleski (red.), Maski współczesności. O literaturze i kulturze XX wieku (s. 75-87). Wydawnictwo IBL PAN.

Leociak, J. (2011). Miejsce-po-getcie. W: Spojrzenia na warszawskie getto (t. 6 - Stawki, s. 39-52). Dom Spotkań z Historią.

Kowalska-Leder, J. (2017). Mur. W: J. Kowalska-Leder, P. Dobrosielski, I. Kurz, M. Szpakowska (red.), Ślady Holokaustu w imaginarium kultury polskiej (s. 245274). Wydawnictwo Krytyki Politycznej.

Melchior, M. (2004). Zagłada a tożsamość. Polscy Żydzi ocaleni „na aryjskich papierach". Wydawnictwo IFiS PAN.

Michejda, A. (2019). Skarb getta. Oficyna 4eM.

Michlic, J. B. (2020). Piętno Zagłady. Wojenna i powojenna historia oraz pamięć żydowskich dzieci ocalałych w Polsce (A. Musiał, tłum.). Żydowski Instytut Historyczny.

Nowak, E. (2018). Kto uratował jedno życie... Historia Ireny Sendlerowej. Egmont.

Orzeł, O. (oprac.). (2014). Dzieci żydowskie w czasach Zagłady. Wczesne świadectwa 1944-1948. Relacje dziecięce ze zbiorów Centralnej Żydowskiej Komisji Historycznej. Żydowski Instytut Historyczny.

Rudniańska, J. (2007). Kotka Brygidy. Pierwsze.

Rudniańska, J. (2012). XY. Muchomor.

Rybak, K. (2016-2020). Oczami dziecka. Zagłada w polskiej literaturze dziecięcej i młodzieżowej po roku 1989. Pobrane 5 kwietnia 2021 z: https://oczamidziecka.al.uw. edu.pl/. 
Rybak, K. (2017). Hide and seek with Nazis: Playing with child identity in Polish children's literature about the Shoah. Libri \& Liberi, 6(1), 11-24. https://doi. org/10.21066/carcl.libri.2017-06(01).0001.

Rybak, K. (2019a). Dzieciństwo w labiryncie getta. Recepcja mitu labiryntu w polskiej literaturze dziecięcej o Zagładzie. Wydawnictwa UW.

Rybak, K. (2019b). I (nie) żyli długo i szczęśliwie. Konstrukcje zakończeń w polskiej literaturze dziecięcej o Zagładzie. Literatura Ludowa, 63(1), 10-23. https://doi. org/10.12775/LL.1.2019.001.

Rybak, K. (2020). Stosunki polsko-żydowskie i Zagłada w polskiej literaturze dziecięcej XXI wieku. W: Z. Trębacz (red.), Stosunki polsko-żydowskie, t. 2: Kultura. Literatura, sztuka i nauka w XX wieku (s. 171-187). Żydowski Instytut Historyczny.

Ryrych, K. (2018). Pan Apoteker. Literatura.

Skowera, M. (2014). Polacy i Żydzi, dzieci i dorośli. Kto jest kim w Kotce Brygidy Joanny Rudniańskiej i Bezsenności Jutki Doroty Combrzyńskiej-Nogali. Konteksty Kultury, 11(1), 57-72. https://doi.org/0.4467/23531991KK.14.005.1751.

Sundmark, B. (2014). "Dragons be here": Teaching children's literature and creative writing with the help of maps. W: A. Reyes-Torres, L.S. Villacañas-de-Castro, B. Soler-Pardo (red.), Thinking through children's literature in the classroom (s. 6478). Cambridge Scholars.

Szczygielski, M. (2013). Arka czasu, czyli wielka ucieczka Rafała od kiedyś przez wtedy do teraz i wstecz. Stentor.

Szczygielski, M. (2015). Arka czasu, czyli wielka ucieczka Rafała od kiedyś przez wtedy do teraz i wstecz. Latarnik. (wyd. oryg. 2013).

Tagore, R. (1916). De Brief van den Koning (The Post Office) (H. Borel, tłum.). W. De Haan.

Tagore, R. (1922). Poczta (J. Stur, odtw.). Monsalwat.

Wells, H. G. (1925). Wehikuł czasu (The Time Machine). Opowieść fantastyczna (b.t.). E. Wende i S-ka. (wyd. oryg. 1895).

Witkowska-Krych, A. (2019). Mniej strachu. Ostatnie chwile z Januszem Korczakiem. Wydawnictwo Akademickie Dialog.

Wójcik-Dudek, M. (2014). Architektura pamięci - (nie)literackie przestrzenie getta. Annales Universitatis Paedagogicae Cracoviensis. Studia Historicolitteraria, 14, 215-224.

Wójcik-Dudek, M. (2016a). W(y)czytać Zagładę. Praktyki postpamięci w polskiej literaturze XXI wieku dla dzieci i młodzieży. Wydawnictwo UŚ.

Wójcik-Dudek, M. (2016b). Zamieszkać w Zagładzie. Geografia Holocaustu w literaturze dla dzieci i młodzieży. W: W. Kostecka, M. Skowera (red.), Geografia krain zmyślonych. Wokół kategorii miejsca i przestrzeni w literaturze dziecięcej, młodzieżowej i fantastycznej (s. 43-56). Wydawnictwo SBP.

Zieliński, J., Majewski, J. S. (2014). Spacerownik po żydowskiej Warszawie. Agora. 